\title{
Market economy needed
}

\section{Moscow}

A transition to a regulated market economy, along with a large-scale decentralization of management, is the prescription given by the Soviet Academy of Sciences for the ailing Soviet economy.

These changes, and a number of urgently needed steps to bring them about, were recommended after a roundtable discussion held at the academy on 9 November, and attended by economists, People's Deputies (members of parliament) and officials from federal ministries and departments.

Many of the recommendations are aimed at 'westernizing' the consumer market: to bring money that is at present held as individual savings back into circulation, housing and land should be put up for sale, and businesses should offer shares to the public; more industrial manpower and resources should be allocated to the production of consumer goods and services; more consumer goods should be imported directly, instead of being made from imported raw materials. At the same time, the academy recommends, measures should be taken to restrain wage growth and restrict credit. With these changes, experts say, inflation will fall from its present rate of 8-10 per cent per year to 5-6 per cent, and consumer shortages will largely disappear in three years.

To support this new strategy of gearing the Soviet economy to the needs of the population, there must be stable investment in heavy industry, a reduction in the output of mines and a slashing of military spending: this will permit the present investment in consumer goods production and the service sector to be doubled, and still allow a 50 per cent increase in social spending.

But the authors of the academy report, which is to be submitted to the Supreme Soviet and to the government, say that it will be impossible to maintain a Westernstyle consumer goods market without complete reform of the pricing system and the creation of free markets in investment and credit, in manpower and in convertible currency. The present system of price-setting, in which the prices of fuels, raw materials and chemicals, for example, can be greater or less than the going world rate by as much as a factor of two, is fundamentally flawed, the report declares, and should be gradually changed. By 1995, the ratio between the numbers of products with fixed and market prices could be 30 to 70 .

With price reform and a massive changeover to wholesale trade, the academy believes that the range of products in short supply would begin to shrink and most goods would then begin to circulate freely on the consumer market. But some economists are more cautious, believing that a radically revised system can succeed only if shortages, and the consequent social tensions, are alleviated first. That problem is inseparably linked with the question of state subsidies for foodstuffs, which now total over 100,000 million rubles a year. Retail price reform would allow this figure to be reduced by as much as 75 per cent, but the population would have to be protected from the inevitable increases in foodstuff prices by comparable increases in income.

Concomitant with all this, a commercial banking system would have to be installed. The report foresees that a free money and investment market, coupled to a realistic foreign exchange rate, could take shape between 1993 and 1995 .

But a genuine market economy has its own set of ailments, notably inflation, unemployment and bankruptcy. To safe- guard the population against these negative effects of reform, the academy proposes, for example, linking wages with some kind of regularly revised and published consumer price index. The future of perestroika depends, the economists assert, on the ability of the government to overcome the public's distrust of the state, which means that the state must give up its universal proprietorial rights and concede the idea of diversified ownership.

The report criticizes draft Soviet legislation on leases, arguing that it constitutes an insufficiently radical reform of state property, and that it should be modified to allow unreservedly the rights of leaseholders to control income from a lease, acquire productive assets and hire labour, provided only that terms are agreed in advance. The academy also comments on a proposed new tax system, and says that the minimum taxable income should be higher and the maximum tax rate, now 80 per cent, lower. Oleg Borisov, Novosti

\section{Nuclear technology for Brazil}

\section{Munich}

DESPITE opposition charges that Brazil has used West German nuclear technology to develop bomb-making capabilities, West Germany last week extended, for five years, an agreement to provide Brazil with more technology. The government withstood a fiery attack in the Bundestag (parliament) from the opposition Social Democrats (SPD) and Green Party, who claimed that the government was pandering to industry. Brazil is a significant importer of West German nuclear technology, which has lost its domestic market.

The government says there is no proof that Brazil can make nuclear weapons, and points to a clause in the Brazilian constitution that forbids Brazil from developing nuclear weapons.

Ulrich Irmer (Free Democrat) cited in an October debate in the Bundestag a report prepared by the West German intelligence service Bundesnachrichtendienst, according to which Brazil is not capable of producing weapons-grade uranium.

Nuclear reactors in Brazil are subject to oversight by the International Atomic Energy Agency in Vienna, and the West German government says it is satisfied with these various safeguards. But the Social Democrats (SPD), who have been pushing for tighter export restrictions in sensitive areas such as nuclear power and chemical weapons (see Nature 337, 678; 1989), say that government is not telling the whole story. Because Brazil has not signed the Nuclear Non-Proliferation Treaty (NPT), SPD Bundestag member
Edelgard Bulmahn argues that it may have a military programme intent on developing weapons. Only by signing the NPT, which would allow international monitoring of all its nuclear facilities, could Brazil give a clear signal that it does not intend to develop weapons.

The SPD cites the Brazilian military's so-called 'parallel programme' to develop nuclear technology as a threat, and says that a reorganization of Brazil's nuclear programme in 1988 legitimized the drive toward nuclear weapons. But Claus Jäger (Christian Democrat), who accused the opposition of trying to "stir up a scandal", says that government is "convinced" that nothing significant had changed. The original West German agreement, signed in 1975, was to provide up to eight nuclear reactors as well as enrichment and reprocessing technology to Brazil over a 15-year period.

Financial problems and technical hitches have led to a scaling-down, and Brazil now plans to build just three reactors.

Nevertheless, Brazil imports a considerable amount of nuclear technology from West German companies. Sources in the Bundestag estimated the value at DM 600 million ( $\$ 330$ million) in 1989 alone, and the collapse of the market for nuclear power plants in West Germany, along with the decision not to reprocess spent nuclear fuel at home, makes the nuclear industry more dependent than ever on foreign markets.

Steven Dickman

- For more on Brazil's nuclear capabilities, see page 374 of the supplement "Science in Brazil".

NATURE · VOL $342 \cdot 23$ NOVEMBER 1989 